\title{
A Sensitive Method for Detecting the Effect of Radiation upon the Human Body
}

\author{
By
}

\author{
K. Motokawa, T. Kohata, M. Komatsu, S. Chichibu, \\ (本川弘一) (木幡正) (小松三夫) (秩父志行) \\ Y. Koga* and T. Kasai* \\ （古賀良彦）（笠井武夫） \\ From the Department of Physiology and the Department of \\ Radiology,* Tohoku University, Sendai
}

(Received for publication, May 1, 1957)

\section{INTRODUCTION}

It is one of the most urgent problems to have a sufficiently sensitive and reliable method available for detecting the effect of radiation upon the human body. The physical methods available at present are extremely sensitive and reliable as well, but can tell nothing about biological effects. There are a number of biological methods to detect the effect of ionizing radiation, but it is generally difficult to apply them to human being. The generally accepted hematological methods are not sufficiently sensitive; a single or accumulated dose of tens or perhaps hundreds of roentgens may be needed for a positive response. ${ }^{1)}$

Motokawa, Umetsu and Kobayashi ${ }^{2}$ showed that the effect of a small dose of X-rays down to several hundred $\mathrm{mr}$ could be detected by their method of electric flicker. Umetsu ${ }^{3)}$ provided evidence that the effect is a biological response of the retina. In this method the electrical threshold of the eye is measured, taking electrical phosphenes, a sensation of light to electrical stimulation of the eye, as an index. The threshold increased following temporal exposure to radiation and subsided in about 30 minutes approximately to the initial level. The threshold dose for this effect was found to be about 1 roentgen. The response is too temporary in marked contrast with the enduring effects revealed by other biological methods. In the present investigation, however, it has been elucidated that in the preceding investigation by Motokawa $e t$ al. a long-lasting effect was overlooked because of insufficient accuracy of the previous method.

The present investigation dates back to the following event in the Department of Physiology : One of the authors, T. K. was engaged in the study of visual physiology. In this research the effect of light upon the electrical 
threshold was measured very accurately using the routine method in the department. T. K. was one of the best subjects for such measurements, for his electrical threshold was accurate and showed only little daily variations. Recently, however, he fell, from time to time, into an enormously confused state in which his threshold was found very high and unstable. Such a state, once started, used to continue for a few to several days. $\mathrm{He}$ was almost giving up his research, because the occurrence of the state was becoming more frequent. We sought for factors likely to be responsible for the state in question, but had no clue. We never thought of an effect of radiation until we were told that he sometimes carried out the fluorography of the chest at a certain hospital as a part-time physician there. Then a survey was made on the coincidence between the state and the fluorography, and it was confirmed that there was a certain correlation between them, and further that the effect was greatly reduced, but not entirely avoided by protecting the eyes with a lead plate. Suspecting the effect of scattered X-rays to be responsible for the state, we consulted one of the authors, Y. K. He doubted, however, the relationship in general, because it seemed to him that the scattered X-rays received by an observer in the usual fluorography would be too small in quantity to cause such a remarkable effect. He rather thought of some failure in radiological technique at the hospital and stressed the importance of careful control of doses. Thus cooperation was started between both departments of physiology and radiology. The dose of ionizing radiation was now controlled with the highest possible accuracy, and thus positive responses were obtained to such a small dose as a few $\mathrm{mr}$.

The present method is based on the same principle as the previous work. The only difference consists in a great improvement in the accuracy of threshold determination; the "rise in sensitivity amounting to $100-1000$ times and confirmation of a long-lasting after-effect of momentary exposure depend solely upon the improvement in the technique for measuring electrical thresholds and careful control of experimental conditions. In the present paper, therefore, the method, especially the procedure for determination of thresholds, will be described in full detail.

\section{EXPERIMENTAL}

\section{Method}

1) Apparatuses necessary for measuring electrical thresholds of the human eye

A single rectangular pulse of $100 \mathrm{msec}$. in duration is applied to the human eye through a pair of silver electrodes of $2 \times 1.5 \mathrm{~cm} . .^{2}$ in size, placed one on the forehead and the other on the temple. The contact of the electrodes with the skin was secured by the use of electrode paste. The circuit for electrical stimulation is shown in Fig. 1. The contacts $S_{1}$ and $S_{2}$ are opened in succession at a 
fixed interval of $100 \mathrm{msec}$. by means of a rheotome illustrated in the same figure. The duration of 100 msec. is about 2 times the utilization time of the rheobasic current. The strength of the stimulating current is controlled by a variable resistance $\mathbf{R}$ in the figure. Another constant resistor of 10 kilo-ohms serves to reduce

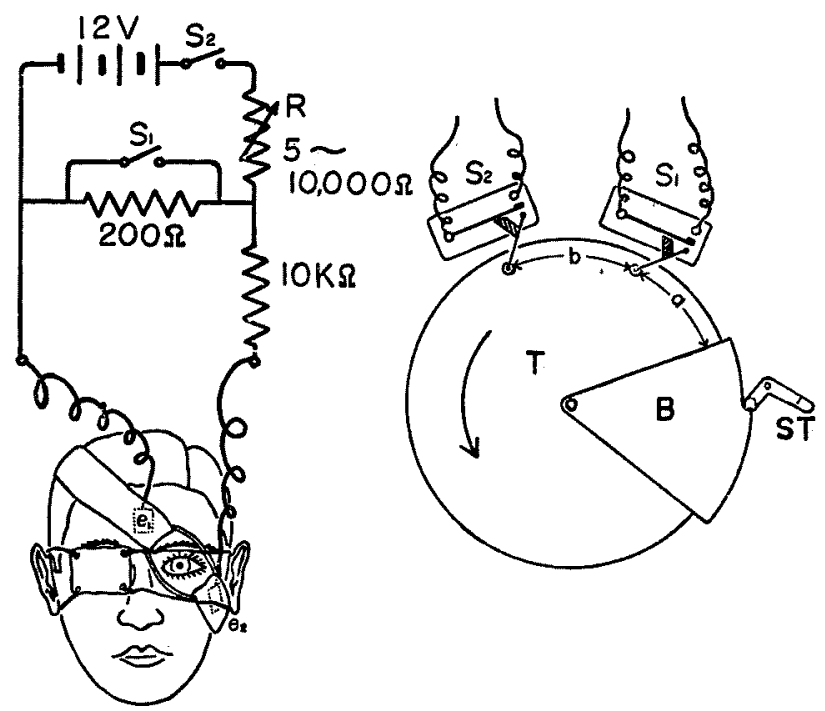

Fig, 1. Arrangements for measuring electrical thresholds of human eye. A rheotome is shown on right. B: Sector which serves to open switches $S_{1}$ and $S_{2}$ when it turns with T. $S_{1}$ and $S_{2}$ : Microswitches. ST: Stop for $B$. $\mathrm{T}$ : Turning board of phonomotor. Further explanation in text.

the effect of variation of the skin resistance. We usually place the cathode on the forehead. A small resistance of $200 \mathrm{ohms}$ is connected in parallel to the tissue, and the voltage applied to both ends of the resistance is calculated after the following formula:

$$
\mathrm{v}=\frac{12 \times 200}{\mathrm{R}+200} \text { volts }
$$

As the contacts of the rheotome " microswitches" are used, which are opened by a revolving sector $B$ and closed by their elasticity when $B$ has passed under each switch. The sector $B$ is put co-axially on a turning board $T$ of a phonomotor and revolves with $\mathrm{T}$ by friction between $\mathrm{B}$ and $\mathrm{T}$. The sector can, however, be brought into standstill by means of a stop ST, while $\mathrm{T}$ is turning. When the sector is released manually, it turns with the same rate as $T$. The switch $S_{1}$ is opened by the anterior edge of $B$, and after a certain interval the other switch $S_{2}$ is opened, the interval being determined by the distance between $S_{1}$ and $S_{2}$ and the revolving rate of $B$. When the trailing edge of $B$ just passes $S_{1}$, this is closed by its elasticity. Thus the subject's eye is shunted so that it is never stimulated until $S_{1}$ is opened again. $S_{2}$ is closed likewise when the trailing edge 
of $B$ passes $S_{2}$, and thus a battery of 12 volts is switched in for the next stimulation. The sector B stops automatically after one revolution. In this way one has only to release the sector B to give a stimulus.

2) The adaptation state of the eye

The electrical threshold of the eye as determined with electrical phosphenes as an index is found lowest several minutes after the onset of dark adaptation, then rises rather rapidly and attains a fairly constant level in about 20 minutes. We usually make measurements after a preliminary dark adaptation of about 20 minutes. But so far as the effect of radiation is concerned, there is no reason to carry out experiments only under dark adaptation; in a preliminary experiment similar effects were obtained under light adaptation. We, however, prefer dark adaptation to light adaptation, because the former may be reproduced easily. During an experiment a fixation point, a faint red light, is used, because eye movement must be avoided in such measurements.

3) Gradation of stimulating currents and determination of thresholds

We usually start with a voltage of 2 volts which correspond to $1000 \mathrm{ohms}$ of R (Fig. 1). Most subjects perceive a distinct phosphene to this stimulus. If the subject fails, the resistance may be reduced to 500 or $300 \mathrm{ohms}$, but it must be borne in mind that such a strong stimulus has a long-lasting after-effect.4) The stimulating voltage is lowered (the resistance is raised) step by step in such a manner as exemplified in Table I. Successive trials are separated by an interval of 15 seconds. When the voltage is so much reduced that the subject finds it difficult to discriminate an electrical phosphene from the background of intrinsic light, he demands a comparison procedure. The procedure consists of delivering at an interval of several seconds in random order two stimuli, one of which is the stimulus in question, and the other a control one of zerovoltage. The subject is requested to answer the question which the strong stimulus is, and informed every time whether his answer is right or wrong. The same procedure is repeated with voltages reduced step by step until the subject can no longer discriminate both stimuli. Near the threshold the voltage is graded by about 1 per cent, because normal subjects can discriminate a difference of about $l$ per cent. If the answer is wrong, the test with the same voltage is repeated, and if the subject fails twice out of three trials, the latest value is adopted as a threshold value. In these tests the subject is allowed to request a further trial when he thinks that his failure was due to some accidental disturbance of attention or due to wrong judgement in spite of a fairly distinct difference perceived between the effects of the two stimuli. In reality, however, such positive cooperation cannot always be hoped from all subjects. In the present experiment in which all the subjects were beginners, a further trial with a stimulating voltage reduced 5 per cent was made to be sure that no positive response appeared below the threshold obtained. Though rarely, successive positive responses were obtained, which indicates that the threshold once determined was not a true one (see Table I, the 3rd column).

The method mentioned above has been established after our long experiences of about 10 years and gives well-reproducible and reliable results, as will be 
TABLE I

Examples of Protocol for Gradation of Stimulating Voltages

Values of resistance $R$ in Fig. 1 are given in ohms. Correct answer is marked by plus sign, wrong answer by minus sign, and no or equal phosphene to both stimuli by circle.

\begin{tabular}{|c|c|c|c|c|c|c|c|}
\hline \multicolumn{2}{|c|}{ N.H. (normal) } & \multicolumn{2}{|c|}{ B.M. (X-ray gr.) } & \multicolumn{2}{|c|}{ K.U. (X-ray gr.) } & \multicolumn{2}{|c|}{ N.C. (X-ray gr.) } \\
\hline $\mathbf{R}$ & Response & $\mathbf{R}$ & Resp. & $\mathbf{R}$ & Resp. & $\mathbf{R}$ & Resp. \\
\hline 1000 & Distinct & 800 & Clear & 1000 & Clear & 800 & Weak \\
\hline 1500 & $"$ & 1000 & Weak & 1500 & $"$ & 1000 & $"$ \\
\hline 1800 & $"$ & 1050 & V. weak & 1800 & Weak & 1100 & ", \\
\hline 2000 & Weak & 1100 & Faint & 2000 & $"$ & 1200 & Faint \\
\hline 2150 & $"$ & 1140 & $"$ & 2100 & Faint & 1240 & T. faint \\
\hline 2250 & Very weak & 1180 & Weak & 2150 & $"$ & \multicolumn{2}{|c|}{ Comparison } \\
\hline 2280 & Faint & 1220 & Faint & 2170 & V. faint & $\begin{array}{l}1260 \\
1280\end{array}$ & $\stackrel{+}{-+}$ \\
\hline 2310 & & 1260 & & 2190 & T. faint & $\begin{array}{l}1300 \\
1320\end{array}$ & + \\
\hline 2340 & Too faint & 1300 & V. faint & \multicolumn{2}{|c|}{ Comparison } & $\begin{array}{l}\mathbf{1 3 4 0} \\
1360\end{array}$ & $\frac{\mathrm{O}}{-0}+$ \\
\hline \multicolumn{2}{|c|}{ Comparison } & & T. faint & $\begin{array}{l}2210 \\
2230\end{array}$ & \pm & Step & $5 \%$ \\
\hline $\begin{array}{l}2370 \\
2400 \\
2430 \\
2460 \\
2490 \\
2520 \\
\text { Ste }\end{array}$ & $\begin{array}{l}+ \\
+ \\
+ \\
+++ \\
++ \\
00 \\
\text { up } 5 \%\end{array}$ & \multirow{2}{*}{\multicolumn{2}{|c|}{$\begin{array}{l}\text { Comparison } \\
1360 \quad+ \\
1380 \quad+ \\
1400 \quad++ \\
1420+ \\
1440+ \\
1460+ \\
1480+ \\
1500 \quad+ \\
1520 \quad-0 \\
\text { Step up 5\% } \\
1600 \quad 0-\end{array}$}} & $\begin{array}{r}\text { Ste } \\
2350 \\
2380 \\
2410 \\
2440 \\
2470\end{array}$ & $\begin{array}{l}\text { up } 5 \% \\
+ \\
+ \\
\frac{+}{0}\end{array}$ & 1440 & 00 \\
\hline 2650 & -0 & & & & & & \\
\hline
\end{tabular}

shown later. The slightest modification can reduce the reliability and accuracy greatly, as pointed out by Kohata et al.4) Therefore it is desirable to follow this procedure as faithfully as possible, before any modification is made.

4) Various factors affecting threshold measurements

a) Resistance of the skin. The absolute value of threshold depends upon the electrical resistance of the tissue, especially the skin. The constant resistance of 10 kilo-ohms in Fig. 1 reduces this effect to some extent. Sweating lowers the resistance of the skin and consequently the threshold. It is, therefore, necessary to maintain the room temperature and ventilation constant.

The absolute value of threshold shows individual and daily variations even under well-controlled experimental conditions. It is, therefore, preferable to use some relative measure comparatively independent of the absolute value. As will be mentioned later, the standard deviation in per cent of the mean 
threshold serves as an excellent indicator for the effect of radiation.

b) Attention and attitude of the subject. Weak phosphenes can be perceived only when the subject concentrates his attention to the phenomenon. It is sometimes difficult for a beginner to concentrate attention to a phosphene appearing in the periphery of the visual field. Electrical phosphenes are sometimes very similar to the intrinsic light of the retina, but have a characteristic that they appear in definite relation to the electric stimulus. In order to make discrimination of phosphenes easier, the subject must be informed of the moment at which the electrical stimulus is given. We give, therefore, at least two anticipatory signals; the one is a verbal signal which is given a few seconds prior to the electric stimulus, and the other the clicks from the switches. It is true that conditioned phosphenes may be evoked by these anticipatory signals alone, but they are avoided by the comparison procedure stated above.

c) Fatigue. Electrical phosphenes are diminished in intensity by fatigue. The method of electric flicker is based on this principle.2) The effect of ionizing radiation as revealed by the present method is not specific to radiation, but very similar to the effect of fatigue. Therefore it is necessary to carry out experiments only in the normal, not fatigued state of the subjects.

d) Practice-effect. In some subjects the value of threshold and its fluctuation decrease as they become more practiced, but in others no remarkable practice-effect can be observed (see Tables II and III). If one session is devoted to practice, the practice-effect may practically be avoided.

5) Dosimetry of ionizing radiation

X-rays were measụred by means of a Küstner's dosimeter. The intensity was controlled by varying the distance between the focus and the eye. The conditions of exposure were as follows: Voltage $70 \mathrm{kVp}$, current $3 \mathrm{~mA}$, filter $0.5 \mathrm{~mm}$. Al, exposure time 1 minute and distance $155 \mathrm{~cm}$. for dose of $50 \mathrm{mr}$. Radium was used when the effect of radiation at a dose less than $50 \mathrm{mr}$ was investigated. For doses of $1 \mathrm{mr}$ and $5 \mathrm{mr}, \mathrm{Ra}$ of $1 \mathrm{mg}$ was held at a distance of $20 \mathrm{~cm}$. in front of the subject's eyes, exposure time being 3 and 15 minutes respectively. For greater doses $\mathrm{Ra}$ of $6 \mathrm{mg}$ was used, the distance being fixed at $20 \mathrm{~cm}$. The measurement by the Küstner's dosimeter was checked further by a pocket-chamber and with a milliroentgen-meter (Toshiba).

\section{Results}

\section{A) The effect of momentary $X$-ray exposure on the electrical threshold of the human} eye

The dose of X-rays used in this series of experiments was $50 \mathrm{mr}$. The subjects were 10 normal university students who were all beginners in such measurements. After a preliminary dark adaptation of about 20 minutes, electrical thresholds were measured 10 times after the procedure described above. The mean of the 10 values and their standard deviation were obtained. Then each subject was exposed to X-rays, and 10-20 minutes after exposure, similar measurements were carried out. The results obtained were consistent in all the cases. Similar measurements were performed on successive several days till 
the after-effect of exposure apparently disappeared. The threshold increased after exposure, and far greater increases were found in the standard deviation. These changes subsided day after day. In some cases a second exposure was carried out several days after the first, and the same changes could be observed.

Strictly speaking, the decay of the threshold value itself or the standard deviation was not so steady in some cases, but it was found that the decay became very smooth in all cases, when the effect was expressed in terms of relative values of standard deviation. This measure has proved to be very useful not only for specifying the effect of momentary exposure, but also certain chronic effects found in persons occupationally exposed to radiation. Therefore this quantity, i.e. standard deviation in percentage of the mean, will be called the "phosphene index" and denoted by a symbol Pi. The phosphene index is defined by the following formula:

$$
\mathrm{Pi}=\frac{100}{\mathrm{M}} \sqrt{\frac{\sum(\mathrm{v}-\mathrm{M})^{2}}{\mathrm{~N}}}
$$

where $\mathrm{v}, \mathrm{M}$, and $\mathrm{N}$ denote each threshold voltage, the mean and the number of measurements, 10 in the present experiment, respectively.

The time-courses of $\mathrm{Pi}$ after exposure to $50 \mathrm{mr}$ are summarized in Fig. 2. As can be seen in this figure, Pi decreases steadily with time. The time necessary for complete recovery could not be determined from this series of experiments, because the practice-effect mentioned above was not ruled out.

B) The effect of radiation as a function of applied doses

The maximum value of $\mathrm{Pi}$ following momentary exposure to ionizing radiation from $\mathrm{Ra}$ was measured on 18 normal subjects including 8 well-trained subjects from the Department of Physiology. The effect is shown as a function of the applied doses in Fig. 3, where $\mathrm{Pi}$ is expressed in terms of $\mathrm{Pi}_{0}$, the pre-exposure value of $\mathrm{Pi}$. As can be seen in this figure, the effect increases almost linearly with the logarithm of the dose applied for smaller doses than $50 \mathrm{mr}$. It is to be noted that such a regular relation has been obtained, although the points in the figure refer to different individuals. We may say definitely that ionizing radiation of a dose as small as $1 \mathrm{mr}$ is effective. If the extrapolation of the curve is allowed, the minimum detectable dose, which is represented by the intersept on the dose-axis, is about $0.4 \mathrm{mr}$. This dose is said to be of the same order as the daily background radiation on the surface of the earth.

C) Enduring effects as found in $X$-ray-technicians and physicians

The phenomenon mentioned above is of great biological importance because of its extremely high sensitivity to ionizing radiation. But if it were a mere temporary effects having no connection with the cumulative effect, which is said to be characteristic of radiation, it would be a mere biological response comparable with the physiological response of the retina to visible light. In reality, the after-effect of momentary exposure endures for a few to several days or longer. There are few parallels to this phenomenon with regard to the duration of the after-effect.

The following series of experiments were undertaken to find any cumulative 


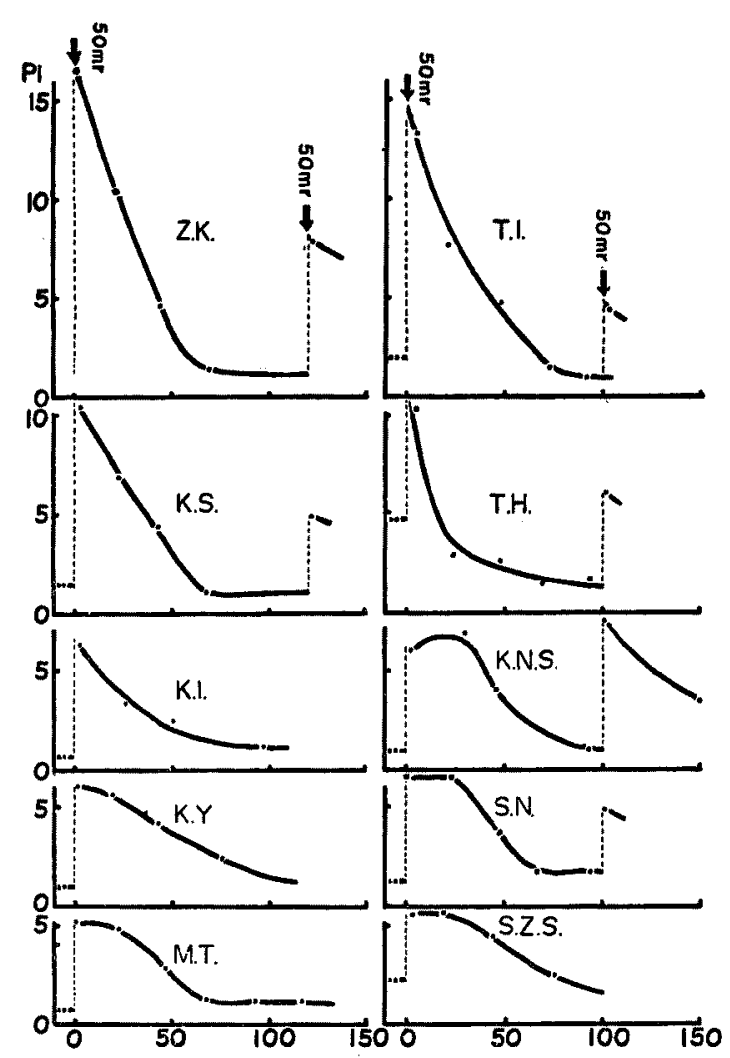

Fig. 2. Effect of X-ray exposure as a function of time in hours after exposure. Ordinate: Phosphene index or standard deviation in per cent of mean of 10 thresholds. Arrows indicate exposure. Subjects : Normal university students.

effects in persons occupationally exposed to ionizing radiation. The subjects were X-ray-technicians and physicians in the Department of Radiology and other hospitals, the number being 21. As control as many normal beginners, mostly university students, were used. In order to avoid any after-effect of the latest exposure, each subject was requested to have a vacation of a week at the shortest. Each subject had four sessions, 10 measurements in each. The protocols are summarized in Tables II and III. The phosphene index remained almost steady in most cases, but that in the first session was remarkably higher in some cases (practice-effect). Therefore the data of the first session were discarded in the following statistical treatment. A histogram was constructed from 63 values of $\mathrm{Pi}$, and is illustrated in Fig. $4 \mathrm{~A}$. The mean value of $63 \mathrm{Pi}$ was $2.50 \pm 1.661 \%$. Similarly another histogram B was constructed from the data of the normal group, the mean value of $\mathrm{Pi}$ being $0.98 \pm 0.346 \%$. As can be seen in the figure, the phosphene index of the X-ray group shows a distribution quite different 


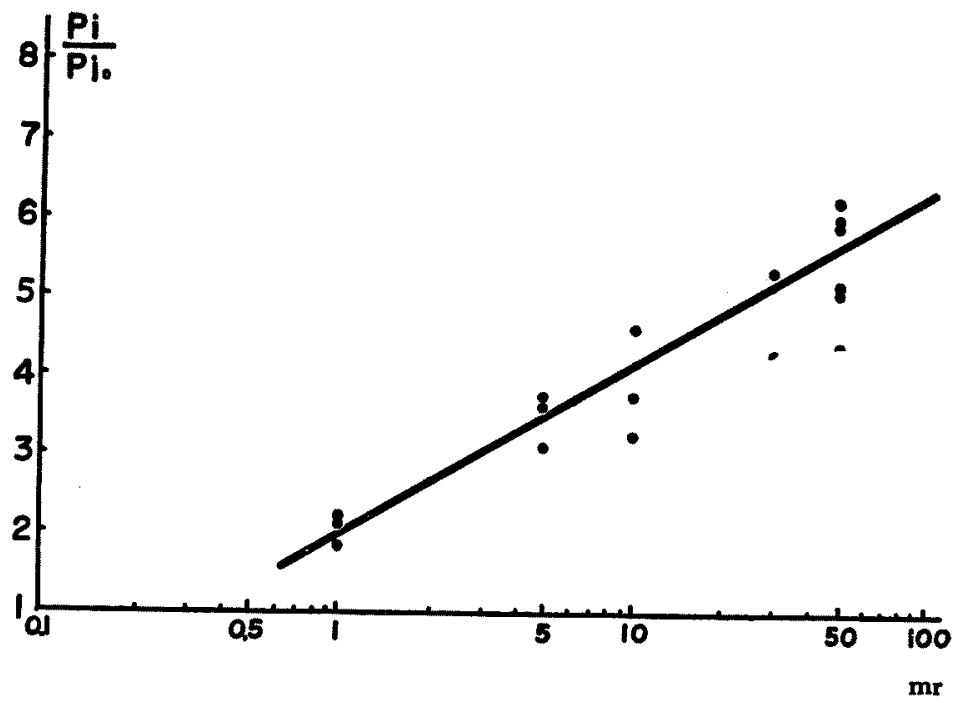

Fig. 3. Effects of ionizing radiation from Radium as a function of applied doses. Ordinate: Phosphene index with pre-exposure value as unit. Abscissa : Logarithm of dose in $\mathrm{mr}$. All points were obtained from different normal subjects.

from that of the control group. There was no subject showing Pi greater than 2.5 in the control group, while the mean value of $\mathrm{Pi}$ was 2.5 in the X-ray group.

The histograms of the two groups overlap each other over a certain limited region of $\mathrm{Pi}$. This fact may be correlated with the circumstance that some individuals in the X-ray group were quite normal not only concerning blood cell counts, but also as to other physical conditions. It is, however, to be noted that values of $\mathrm{Pi}$ smaller than 0.9 were found 21 in number in the normal group, while there was no such small value in the X-ray group. This is a fact suggesting that the capacity to discriminate electrical phosphenes is more or less impaired even in apparently normal subjects of the X-ray group. In this way a cumulative effect of radiation has been demonstrated by the present method.

For comparison, histograms of threshold voltages were constructed likewise and are illustrated in Fig. 5. The mean of the thresholds for the X-ray group was $1.686 \pm 0.8907$ volts, and that for the normal group $1.414 \pm 0.4471$ volts. As can be seen in the figure, the overlap of both histograms is far more remarkable for threshold voltages than for phosphene indices; the difference between both groups is hardly significant when threshold voltages are taken as an index. This is one of the reasons why we prefer the phosphene index to the threshold voltage itself.

D) Summation of the effects of $X$-ray exposures and the duration of the after-effect

In order to study the summation of the effects of exposures, two well-trained subjects were exposed to X-ray irradiation with a dose of $50 \mathrm{mr}$ every day or every two days, and changes of Pi were observed for about 2 weeks. The results are illustrated in Fig. 6. As can be seen in this figure, the phosphene index 
TABLE II

The Mean of Threshold Voltages in Volts (M), Standard

Deviation in Volts (S. D.) and Phosphene Index in. \%

$(\mathrm{Pi})$ in Each Subject of Control Group

\begin{tabular}{|c|c|c|c|c|c|}
\hline $\begin{array}{l}\text { Name of subj.; } \\
\text { Profession; Age }\end{array}$ & & $\begin{array}{c}\text { Session } \\
1\end{array}$ & $\begin{array}{l}\text { Session } \\
2\end{array}$ & $\begin{array}{c}\text { Session } \\
3\end{array}$ & $\begin{array}{c}\text { Session } \\
4\end{array}$ \\
\hline $\begin{array}{c}\text { T.O. } \\
\text { Student } \\
25\end{array}$ & $\begin{array}{c}\text { M } \\
\text { S.D. } \\
\text { Pi }\end{array}$ & $\begin{array}{l}1.094 \\
0.0417 \\
3.81\end{array}$ & $\begin{array}{l}0.994 \\
0.0075 \\
0.76\end{array}$ & $\begin{array}{l}1.068 \\
0.0075 \\
0.70\end{array}$ & $\begin{array}{l}1.026 \\
0.0082 \\
0.80\end{array}$ \\
\hline $\begin{array}{c}\text { S.C. } \\
\text { Student } \\
25\end{array}$ & & $\begin{array}{l}0.748 \\
0.0055 \\
0.74\end{array}$ & $\begin{array}{l}0.721 \\
0.0044 \\
0.61\end{array}$ & $\begin{array}{l}0.701 \\
0.0025 \\
0.36\end{array}$ & $\begin{array}{l}0.701 \\
0.0038 \\
0.54\end{array}$ \\
\hline $\begin{array}{c}\text { N.T. } \\
\text { Student } \\
25\end{array}$ & & $\begin{array}{l}1.192 \\
0.0271 \\
2.27\end{array}$ & $\begin{array}{l}1.173 \\
0.0188 \\
1.60\end{array}$ & $\begin{array}{l}1.005 \\
0.0060 \\
0.60\end{array}$ & $\begin{array}{l}0.840 \\
0.0076 \\
0.90\end{array}$ \\
\hline $\begin{array}{c}\text { E.Y. } \\
\text { Laborant } \\
32\end{array}$ & & $\begin{array}{l}0.981 \\
0.0116 \\
1.18\end{array}$ & $\begin{array}{l}0.820 \\
0.0070 \\
0.85\end{array}$ & $\begin{array}{l}0.812 \\
0.0084 \\
1.04\end{array}$ & $\begin{array}{l}0.787 \\
0.0073 \\
0.93\end{array}$ \\
\hline $\begin{array}{c}\text { Y.O. } \\
\text { Student } \\
22\end{array}$ & & $\begin{array}{l}1.262 \\
0.0424 \\
3.36\end{array}$ & $\begin{array}{l}1.173 \\
0.0135 \\
1.15\end{array}$ & $\begin{array}{l}1.146 \\
0.0126 \\
1.10\end{array}$ & $\begin{array}{l}1.554 \\
0.0125 \\
0.80\end{array}$ \\
\hline $\begin{array}{c}\text { N.H. } \\
\text { Student } \\
22\end{array}$ & & $\begin{array}{l}1.154 \\
0.0233 \\
2.03\end{array}$ & $\begin{array}{l}1.043 \\
0.0080 \\
0.77\end{array}$ & $\begin{array}{l}0.901 \\
0.0071 \\
0.78\end{array}$ & $\begin{array}{l}0.997 \\
0.0079 \\
0.79\end{array}$ \\
\hline $\begin{array}{c}\text { M.A. } \\
\text { Student } \\
21\end{array}$ & & $\begin{array}{l}1.340 \\
0.0202 \\
1.51\end{array}$ & $\begin{array}{l}1.337 \\
0.0111 \\
0.83\end{array}$ & $\begin{array}{l}1.277 \\
0.0106 \\
0.83\end{array}$ & $\begin{array}{l}1.163 \\
0.0159 \\
1.37\end{array}$ \\
\hline $\begin{array}{c}\text { R.K. } \\
\text { Student } \\
23\end{array}$ & & $\begin{array}{l}0.980 \\
0.0136 \\
1.39\end{array}$ & $\begin{array}{l}1.020 \\
0.0097 \\
0.95\end{array}$ & $\begin{array}{l}0.847 \\
0.0060 \\
0.71\end{array}$ & $\begin{array}{l}0.857 \\
0.0042 \\
0.49\end{array}$ \\
\hline $\begin{array}{c}\text { O.S. } \\
\text { Student } \\
22\end{array}$ & & $\begin{array}{l}1.782 \\
0.0199 \\
1.12\end{array}$ & $\begin{array}{l}1.543 \\
0.0287 \\
1.86\end{array}$ & $\begin{array}{l}1.814 \\
0.0261 \\
1.44\end{array}$ & $\begin{array}{l}1.691 \\
0.0137 \\
0.81\end{array}$ \\
\hline $\begin{array}{c}\text { N.M. } \\
\text { Student } \\
22\end{array}$ & & $\begin{array}{l}2.201 \\
0.0710 \\
3.22\end{array}$ & $\begin{array}{l}1.597 \\
0.0198 \\
1.24\end{array}$ & $\begin{array}{l}1.646 \\
0.0134 \\
0.81\end{array}$ & $\begin{array}{l}1.314 \\
0.0102 \\
0.78\end{array}$ \\
\hline $\begin{array}{l}\text { G.S. } \\
\text { Student } \\
21\end{array}$ & & $\begin{array}{l}2.355 \\
0.0156 \\
0.66\end{array}$ & $\begin{array}{l}1.409 \\
0.0124 \\
0.88\end{array}$ & $\begin{array}{l}1.282 \\
0.0083 \\
0.65\end{array}$ & $\begin{array}{l}1.259 \\
0.0100 \\
0.79\end{array}$ \\
\hline $\begin{array}{c}\text { C.K. } \\
\text { Student } \\
20\end{array}$ & & $\begin{array}{l}2.185 \\
0.0343 \\
1.57\end{array}$ & $\begin{array}{l}1.916 \\
0.0230 \\
1.20\end{array}$ & $\begin{array}{l}1.780 \\
0.0197 \\
1.11\end{array}$ & $\begin{array}{l}1.338 \\
0.0096 \\
0.72\end{array}$ \\
\hline $\begin{array}{c}\text { S.I. } \\
\text { Student } \\
19\end{array}$ & & $\begin{array}{l}1.189 \\
0.0128 \\
1.08\end{array}$ & $\begin{array}{l}0.857 \\
0.0074 \\
0.85\end{array}$ & $\begin{array}{l}0.952 \\
0.0100 \\
1.05\end{array}$ & $\begin{array}{l}0.961 \\
0.0042 \\
0.44\end{array}$ \\
\hline
\end{tabular}




\begin{tabular}{|c|c|c|c|c|}
\hline $\begin{array}{c}\text { T.S. } \\
\text { Student } \\
22\end{array}$ & $\begin{array}{l}1.756 \\
0.0419 \\
2.38\end{array}$ & $\begin{array}{l}1.843 \\
0.0293 \\
1.59\end{array}$ & $\begin{array}{l}1.823 \\
0.0416 \\
2.28\end{array}$ & $\begin{array}{l}1.815 \\
0.0267 \\
1.47\end{array}$ \\
\hline $\begin{array}{c}\text { G.M. } \\
\text { Student } \\
19\end{array}$ & $\begin{array}{l}0.959 \\
0.0113 \\
1.18\end{array}$ & $\begin{array}{l}0.954 \\
0.0097 \\
1.02\end{array}$ & $\begin{array}{l}0.824 \\
0.0049 \\
0.60\end{array}$ & $\begin{array}{l}0.765 \\
0.0049 \\
0.64\end{array}$ \\
\hline $\begin{array}{l}\text { J.M. } \\
\text { Student } \\
23\end{array}$ & $\begin{array}{l}1.931 \\
0.0201 \\
1.08\end{array}$ & $\begin{array}{l}1.720 \\
0.0245 \\
1.43\end{array}$ & $\begin{array}{l}1.678 \\
0.0148 \\
0.88\end{array}$ & $\begin{array}{l}1.490 \\
0.0180 \\
1.21\end{array}$ \\
\hline $\begin{array}{l}\text { S.T. } \\
\text { Student } \\
22\end{array}$ & $\begin{array}{l}1.463 \\
0.0154 \\
1.05\end{array}$ & $\begin{array}{l}1.501 \\
0.0146 \\
0.97\end{array}$ & $\begin{array}{l}1.617 \\
0.0226 \\
1.40\end{array}$ & $\begin{array}{l}1.825 \\
0.0176 \\
0.96\end{array}$ \\
\hline $\begin{array}{l}\text { R.K. } \\
\text { Student } \\
\quad 22\end{array}$ & $\begin{array}{l}1.722 \\
0.0241 \\
1.40\end{array}$ & $\begin{array}{l}0.888 \\
0.0075 \\
0.85\end{array}$ & $\begin{array}{l}0.813 \\
0.0054 \\
0.66\end{array}$ & $\begin{array}{l}0.850 \\
0.0068 \\
0.80\end{array}$ \\
\hline $\begin{array}{l}\text { T.S. } \\
\text { Student } \\
\quad 22\end{array}$ & $\begin{array}{l}2.130 \\
0.1400 \\
6.56\end{array}$ & $\begin{array}{l}2.024 \\
0.0304 \\
1.50\end{array}$ & $\begin{array}{l}1.171 \\
0.0224 \\
1.91\end{array}$ & $\bar{E}$ \\
\hline $\begin{array}{l}\text { K.M. } \\
\text { Professor } \\
53\end{array}$ & E & $\begin{array}{l}0.596 \\
0.0050 \\
0.84\end{array}$ & $\begin{array}{l}0.594 \\
0.0046 \\
0.79\end{array}$ & $\begin{array}{l}0.593 \\
0.0040 \\
0.67\end{array}$ \\
\hline
\end{tabular}

rises immediately after each exposure and subsides steeply, but never recovers to the preceding level. The effect of the next irradiation is added to the residual effect of the preceding one, and thus the curve of Pi rises slowly as a whole. So a striking resemblance is seen between this effect and the incomplete tetanus of the skeletal muscle. The total dose used was within the maximum permissible dose in both cases. Nevertheless it took a very long time for complete recovery. Two phases, acute and chronic, may be distinguishable in the curve of Pi. The acute phase lasts for a few days, and at the end of this phase the rate of change in $\mathrm{Pi}$ is slowed down remarkably. The recovery in the chronic phase was so protracted that it was not yet complete after 10 days from the latest exposure. It is likely that the cumulative effect as found in the X-ray group is based on such a protracted after-effect.

In any case the chronic effect is far less conspicuous than the acute one. The former is comparable with the tonus, and the latter with a contraction of the muscle. Because of the small magnitude the chronic effect tends to be overlooked when the accuracy of measurement is not sufficient.

The question was raised as to whether the acute response of persons constantly exposed to weak radiation was different in any respect from the normal one observed above. One subject $\mathrm{H}$. E. of the X-ray group, whose resting value of $\mathrm{Pi}$ was 1.05 , showed a value 1.91 when at work. Immediately after exposure to $50 \mathrm{mr}$ the value increased to 5.02 . Another subject $\mathrm{K}$. U. with a resting value of 1.71 and a value at work 3.18 showed such a high value as 12.3 following exposure to $50 \mathrm{mr}$. These findings give, however, no conclusive answer to the question raised above. The question must be studied in further experiment. 


\section{TAB LE III}

The Mean of Threshold Voltages in Volts (M), Standard Deviation in Volts (S. D.) and Phosphene Index in \%

(Pi) in Each Subject of X-Ray Group

In remarks are given years of professional work, leucocyte count and days of vacation in order.

\begin{tabular}{|c|c|c|c|c|c|c|}
\hline $\begin{array}{l}\text { Name of subj.; } \\
\text { Profession; Age }\end{array}$ & & $\begin{array}{c}\text { Session } \\
1\end{array}$ & $\begin{array}{l}\text { Session } \\
2\end{array}$ & $\begin{array}{c}\text { Session } \\
3\end{array}$ & $\begin{array}{l}\text { Session } \\
4\end{array}$ & Remarks \\
\hline $\begin{array}{c}\text { Y.T: } \\
\text { Physician } \\
34\end{array}$ & $\begin{array}{c}\text { M } \\
\text { S.D. } \\
\text { Pi }\end{array}$ & $\begin{array}{l}1.640 \\
0.0378 \\
2.30\end{array}$ & $\begin{array}{l}1.271 \\
0.0150 \\
1.18\end{array}$ & $\begin{array}{l}1.143 \\
0.0134 \\
1.17\end{array}$ & $\begin{array}{l}1.394 \\
0.0158 \\
1.13\end{array}$ & $\begin{array}{l}8 \text { years } \\
5900 \\
9 \text { days }\end{array}$ \\
\hline $\begin{array}{c}\text { K.S. } \\
\text { Technician } \\
43\end{array}$ & & $\begin{array}{l}1.052 \\
0.0268 \\
2.58\end{array}$ & $\begin{array}{l}1.223 \\
0.0290 \\
2.37\end{array}$ & $\begin{array}{l}1.084 \\
0.0173 \\
1.59\end{array}$ & $\begin{array}{l}1.148 \\
0.0238 \\
2.07\end{array}$ & $\begin{array}{l}18 \text { years } \\
7400 \\
9 \text { days }\end{array}$ \\
\hline $\begin{array}{l}\text { N.W. } \\
\text { Physician } \\
28\end{array}$ & & $\begin{array}{l}2.640 \\
0.1940 \\
7.35\end{array}$ & $\begin{array}{l}2 \cdot 347 \\
0.0500 \\
2.13\end{array}$ & $\begin{array}{l}1.806 \\
0.0340 \\
1.88\end{array}$ & $\begin{array}{l}1.812 \\
0.0696 \\
3.84\end{array}$ & $\begin{array}{l}3 \text { years } \\
5600 \\
9 \text { days }\end{array}$ \\
\hline $\begin{array}{l}\text { H.K.M. } \\
\text { Physician } \\
32\end{array}$ & & $\begin{array}{l}1.449 \\
0.0324 \\
2.24\end{array}$ & $\begin{array}{l}1.227 \\
0.0161 \\
1.31\end{array}$ & $\begin{array}{l}1.223 \\
0.0273 \\
2.23\end{array}$ & $\begin{array}{l}1.196 \\
0.0128 \\
1.07\end{array}$ & $\begin{array}{l}7 \text { years } \\
6500 \\
9 \text { days }\end{array}$ \\
\hline $\begin{array}{c}\text { T.K. } \\
\text { Physician } \\
29\end{array}$ & & $\begin{array}{l}1.058 \\
0.0285 \\
2.70\end{array}$ & $\begin{array}{l}1.010 \\
0.0099: \mathrm{j} \\
0.98\end{array}$ & $\begin{array}{l}0.948 \\
0.0109 \\
1.13\end{array}$ & $\begin{array}{l}0.816 \\
0.0091 \\
1.12\end{array}$ & $\begin{array}{l}3 \text { years } \\
4100 \\
9 \text { days }\end{array}$ \\
\hline $\begin{array}{l}\text { Y.K. } \\
\text { Professor } \\
56\end{array}$ & & $\begin{array}{l}2.151 \\
0.0358 \\
1.67\end{array}$ & $\begin{array}{l}2.688 \\
0.0469 \\
1.74\end{array}$ & $\begin{array}{l}2.704 \\
0.0511 \\
1.89\end{array}$ & $\begin{array}{l}1.695 \\
0.0260 \\
1.54\end{array}$ & $\begin{array}{l}20 \text { years } \\
3800 \\
9 \text { days }\end{array}$ \\
\hline $\begin{array}{c}\text { G.N. } \\
\text { Physician } \\
32\end{array}$ & & $\begin{array}{l}1.273 \\
0.0112 \\
0.88\end{array}$ & $\begin{array}{l}1.219 \\
0.0312 \\
2.56\end{array}$ & $\begin{array}{l}1.529 \\
0.0328 \\
2.15\end{array}$ & $\begin{array}{l}1.434 \\
0.0180 \\
1.26\end{array}$ & $\begin{array}{l}3 \text { years } \\
3100 \\
6 \text { days }\end{array}$ \\
\hline $\begin{array}{c}\text { S.S. } \\
\text { Technician } \\
40\end{array}$ & & $\begin{array}{l}5.301 \\
0.2490 \\
4.69\end{array}$ & $\begin{array}{l}5.292 \\
0.3740 \\
7.07\end{array}$ & $\begin{array}{l}3.420 \\
0.2810 \\
8.21\end{array}$ & $\begin{array}{l}5.570 \\
0.5490 \\
9.85\end{array}$ & $\begin{array}{l}22 \text { years } \\
5400 \\
11 \text { days }\end{array}$ \\
\hline $\begin{array}{c}\text { H.E. } \\
\text { Technician } \\
31\end{array}$ & & $\begin{array}{l}1.138 \\
0.0107 \\
0.94\end{array}$ & $\begin{array}{l}1.072 \\
0.0115 \\
1.07\end{array}$ & $\begin{array}{l}0.935 \\
0.0080 \\
0.85\end{array}$ & $\begin{array}{l}0.789 \\
0.0098 \\
1.24\end{array}$ & $\begin{array}{l}8 \text { years } \\
8300 \\
7 \text { days }\end{array}$ \\
\hline $\begin{array}{c}\text { K.U. } \\
\text { Physician } \\
29\end{array}$ & & $\begin{array}{l}2.277 \\
0.0660 \\
2.90\end{array}$ & $\begin{array}{l}1.149 \\
0.0194 \\
1.69\end{array}$ & $\begin{array}{l}0.923 \\
0.0178 \\
1.93\end{array}$ & $\begin{array}{l}0.895 \\
0.0136 \\
1.52\end{array}$ & $\begin{array}{l}2.5 \text { years } \\
6700 \\
6 \text { days }\end{array}$ \\
\hline $\begin{array}{c}\text { B.M. } \\
\text { Technician } \\
38\end{array}$ & & $\begin{array}{l}1.660 \\
0.0716 \\
4.31\end{array}$ & $\begin{array}{l}1.451 \\
0.0396 \\
2.73\end{array}$ & $\begin{array}{l}1.649 \\
0.0306 \\
1.86\end{array}$ & $\begin{array}{l}1.398 \\
0.0426 \\
3.05\end{array}$ & $\begin{array}{l}7 \text { years } \\
3400 \\
7 \text { days }\end{array}$ \\
\hline $\begin{array}{l}\text { H.H.M. } \\
\text { Technician } \\
45\end{array}$ & & $\begin{array}{l}1.199 \\
0.0267 \\
2.23\end{array}$ & $\begin{array}{l}1.199 \\
0.0386 \\
3.22\end{array}$ & $\begin{array}{l}1.256 \\
0.0448 \\
3.57\end{array}$ & $\begin{array}{l}1.221 \\
0.0313 \\
2.56\end{array}$ & $\begin{array}{l}21 \text { years } \\
3200 \\
7 \text { days }\end{array}$ \\
\hline
\end{tabular}




\begin{tabular}{|c|c|c|c|c|c|}
\hline $\begin{array}{c}\text { C.I. } \\
\underset{29}{\text { Technician }}\end{array}$ & $\begin{array}{l}1.548 \\
0.1500 \\
9.69\end{array}$ & $\begin{array}{l}1.802 \\
0.0811 \\
4.51\end{array}$ & $\begin{array}{l}1.580 \\
0.0446 \\
2.83\end{array}$ & $\begin{array}{l}1.950 \\
-0.1020 \\
5.23\end{array}$ & $\begin{array}{l}6 \text { years } \\
6300 \\
7 \text { days }\end{array}$ \\
\hline $\begin{array}{c}\text { N.C. } \\
\text { Technician } \\
45\end{array}$ & $\begin{array}{l}1.008 \\
0.0184 \\
1.83\end{array}$ & $\begin{array}{l}1.168 \\
0.0271 \\
2.32\end{array}$ & $\begin{array}{l}1.083 \\
0.0246 \\
2.27\end{array}$ & $\begin{array}{l}1.506 \\
0.0459 \\
3.04\end{array}$ & $\begin{array}{l}28 \text { years } \\
5200 \\
6 \text { days }\end{array}$ \\
\hline $\begin{array}{c}\text { S.M. } \\
\text { Technician } \\
21\end{array}$ & $\begin{array}{l}2.753 \\
0.0689 \\
2.51\end{array}$ & $\begin{array}{l}3.255 \\
0.0476 \\
1.47\end{array}$ & $\begin{array}{ll}1.644 \\
0.0229 \\
1.39\end{array}$ & $\begin{aligned} & \because 2.543 \\
& 0.0533 \\
& 2.09\end{aligned}$ & $\begin{array}{l}1 \text { year } \\
8700 \\
6 \text { days }\end{array}$ \\
\hline $\begin{array}{l}\text { S.K. } \\
\text { Techniciah } \\
31\end{array}$ & $\begin{array}{l}4.084 \\
0.0673 \\
1.65\end{array}$ & $\begin{array}{l}1.353 \\
0.0302 \\
2.23\end{array}$ & $\begin{array}{l}2.120 \\
0.1102 \\
5.20\end{array}$ & $\begin{array}{l}1.146 \\
0.0221 \\
1.93\end{array}$ & $\begin{array}{l}8 \text { years } \\
7000 \\
7 \text { days }\end{array}$ \\
\hline $\begin{array}{c}\text { M.K. } \\
\underset{36}{\text { Technician }}\end{array}$ & $\begin{array}{l}1.870 \\
0.0734 \\
3.92\end{array}$ & $\begin{array}{l}1.839 \\
0.0471 \\
2.56\end{array}$ & $\begin{array}{l}1.633 \\
0.0334 \\
2.04\end{array}$ & $\begin{array}{l}1.361 \\
0.0220 \\
1.62\end{array}$ & $\begin{array}{l}8 \text { years } \\
6200 \\
6 \text { days }\end{array}$ \\
\hline $\begin{array}{c}\text { H.S. } \\
\text { Technician } \\
23\end{array}$ & $\begin{array}{l}2.644 \\
0.0408 \\
1.54\end{array}$ & $\begin{array}{l}2.058 \\
0.0286 \\
1.39\end{array}$ & $\begin{array}{l}2.231 \\
0.0531 \\
2.38\end{array}$ & $\begin{array}{l}2.331 \\
0.0742 \\
3.19\end{array}$ & $\begin{array}{l}4 \text { years } \\
6000 \\
6 \text { days }\end{array}$ \\
\hline $\begin{array}{c}\text { H.T. } \\
\text { Physician } \\
41\end{array}$ & $\begin{array}{l}3.015 \\
0.0826 \\
2.74\end{array}$ & $\begin{array}{l}2.965 \\
0.0625 \\
2.11\end{array}$ & $\begin{array}{l}1.478 \\
0.0706 \\
4.78\end{array}$ & $\begin{array}{l}1.151 \\
0.0174 \\
1.51\end{array}$ & $\begin{array}{l}8 \text { years } \\
6000 \\
7 \text { days }\end{array}$ \\
\hline $\begin{array}{l}\text { M.I. } \\
\text { Physician } \\
43\end{array}$ & $\begin{array}{l}3.184 \\
0.0962 \\
3.02\end{array}$ & $\begin{array}{l}1.956 \\
0.0585 \\
2.99\end{array}$ & $\begin{array}{l}1.662 \\
0.0558 \\
3.36\end{array}$ & $\begin{array}{l}1.153 \\
0.0350 \\
3.02\end{array}$ & $\begin{array}{l}10.5 \text { years } \\
4000 \\
6 \text { days }\end{array}$ \\
\hline $\begin{array}{c}\text { S.T. } \\
\text { Technician } \\
36\end{array}$ & $\begin{array}{l}1.388 \\
0.0288 \\
2.08\end{array}$ & $\begin{array}{l}1.337 \\
0.0223 \\
1.67\end{array}$ & $\begin{array}{l}1.368 \\
0.0279 \\
2.04\end{array}$ & $\begin{array}{l}1.333 \\
0.0215 \\
1.61\end{array}$ & $\begin{array}{l}13 \text { years } \\
3800 \\
4 \text { days }\end{array}$ \\
\hline
\end{tabular}

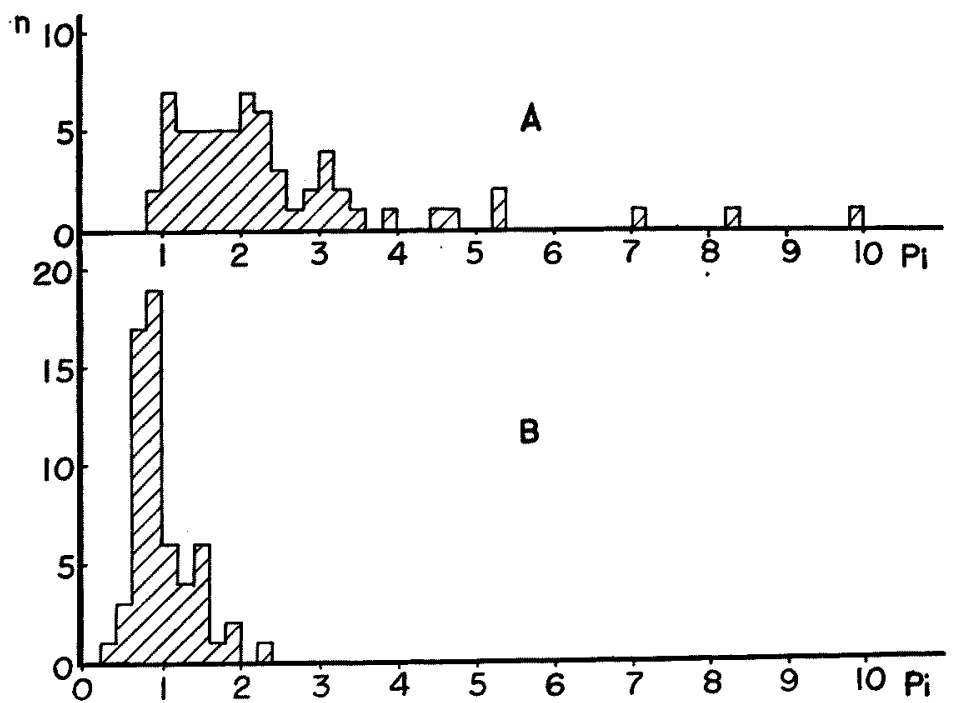

Fig. 4. Histograms of phosphene indices. A and B refer to X-ray group and control one respectively. The former consisted of $21 \mathrm{X}$-ray-technicians and physicians who were not at work before and during experiment. 


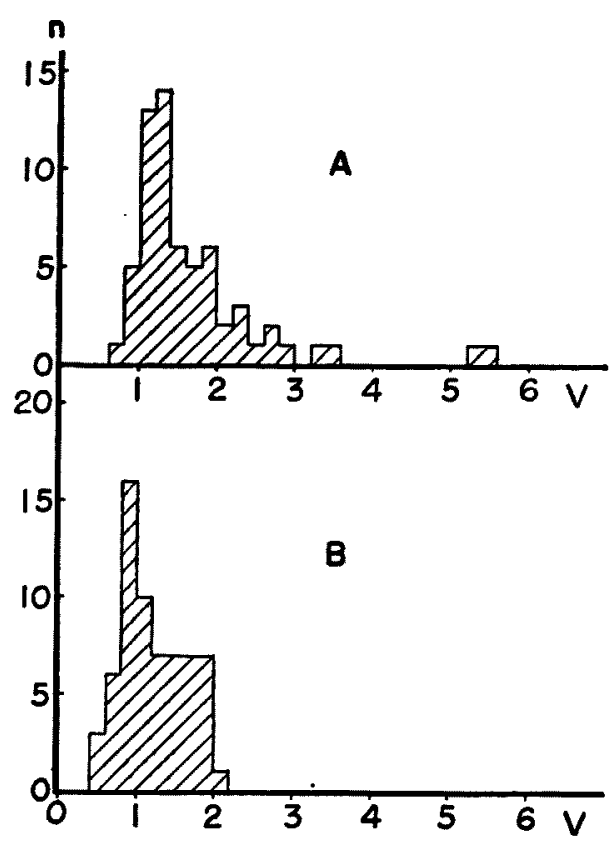

Fig. 5. Histograms of threshold voltages. A and B refer to X-ray group and normal control respectively.

\section{Discussion}

The acute effect is clear-cut and sufficiently sensitive to ionizing radiation, while the chronic effect is obscure and perhaps insensitive; it seems likely that thousand times as large doses would be necessary to cause a chronic effect as conspicuous as the acute effect observed above.

It is an interesting question whether or not the present effects are related with the hematological changes. The leucocyte counts of the Xray group were either normal or a little lower than normal (see Table III). The phosphene indices measured in the chronic phase were either normal or higher than normal. In this sense we may say that some correlation exists between the two phenomena. We made, however, no statistical treatment of the correlation, because our hematological material was not uniform enough with regard to the measuring technique, the laboratories where the measurements were carried out and date.

As to the sensitivity of the blood to ionizing radiation, the results obtained hitherto are too contradictory to one another. Wakabayashi et al. ${ }^{5}$ observed that the number of lymphocytes showed a statistically significant decrease after momentary exposure in radiography and fluorography (received doses 16-60 mr), and that the effect was most marked after 30 minutes and disappeared in 60 minutes. Helde \& Wahlberg ${ }^{6)}$ re- 


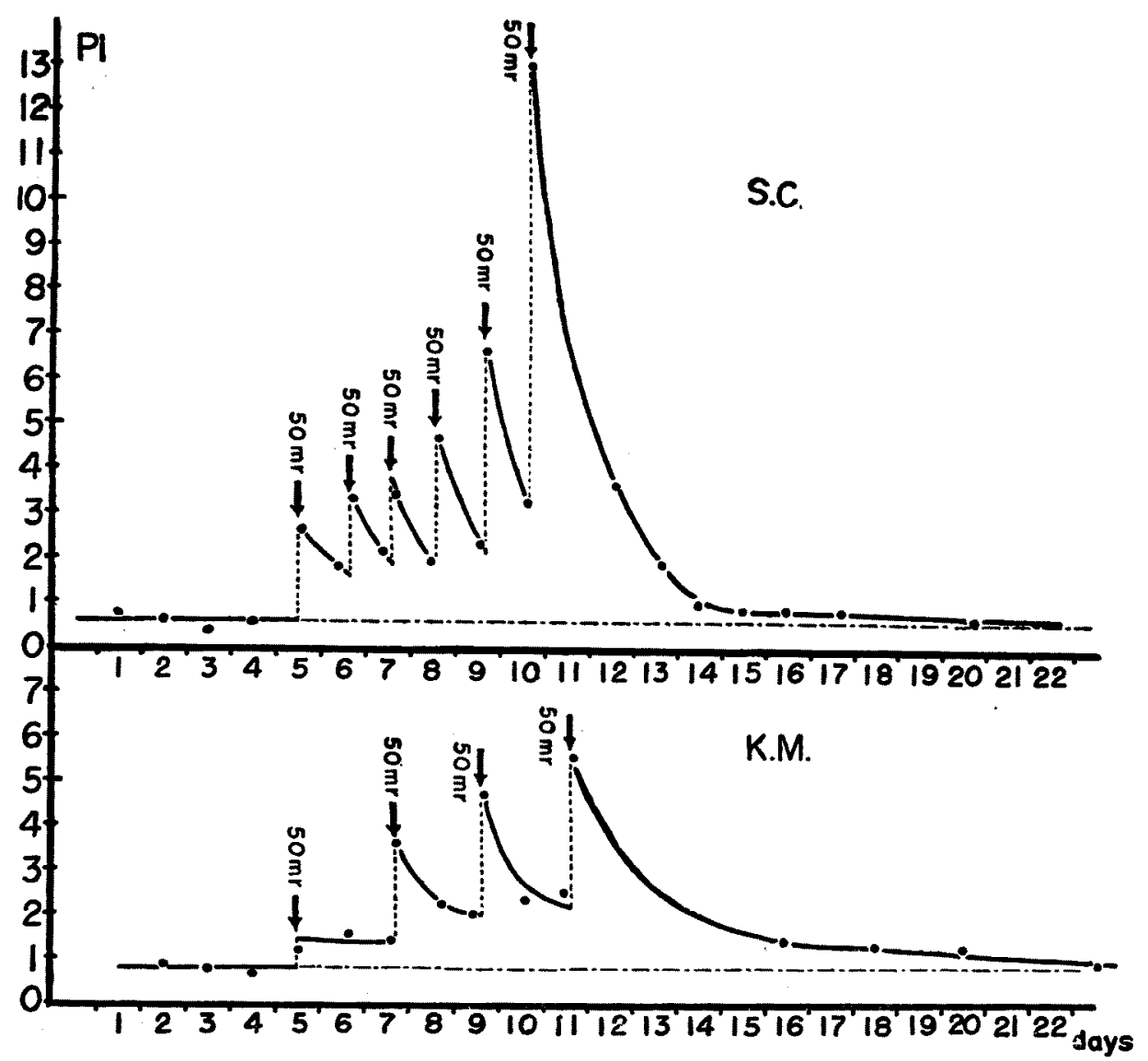

Fig. 6. Summation of effects and protracted recovery.

ported that an appreciable change in blood picture was seen in response to $0.1 \mathrm{mr}$ if the dose was referred to time unit of 0.1 second. They are of the opinion that the effect is comparatively independent of the dose per day, week, etc. so far as the dose is sufficiently small, but that the effect depends greatly upon the rate (quantity per unit time). The results by those authors are in marked contrast with the experiences of others who had to give hundreds of roentgens in order to cause significant hematological changes. ${ }^{21}$

If these results suggesting very high sensitivity of some hematological methods are not based on any technical failures or conscious and unconscious biases of the investigators, there must be some interpretation to reconcile the contradictory results. The present investigation seems to offer such an interpretation. As has been stated above, two kinds of effect, acute and chronic, may be distinguished, and the same may be true of 
hematological changes. The acute hematological change is more sensitive to radiation, but subsides rapidly as in the experiment by Wakabaysh et al., while the chronic effect is far less sensitive, but remains for a long period as in most experiments. If this view is correct, the unusual conclusion by Helde and Wahlberg is not difficult to understand; if their experiment really refers to the acute effect, the response will not depend on the total dose administered over a very long period, because the acute effect declines so rapidly that no complete summation occurs of the effects of individual exposures.

\section{Summary}

The effect of ionizing radiation was investigated upon the electrical threshold of the eye as determined with electrical phosphenes as an index. The present experiment dates back to a chance observation that an enormous increase in electrical threshold of the eye and a conspicuous rise in standard deviation of threshold values occurred after a fluorography of the chest and continued for several days.

1. In 10 normal subjects, who were beginners in such measurements, definitely positive responses were obtained to X-ray irradiation with a dose of $50 \mathrm{mr}$.

2. It was found that the standard deviation in percentage of the mean of thresholds was a better indicator of the effect of radiation than the othreshold value itself. This measure was designated the "phosphene index" and denoted by Pi.

3. The phosphene index was found decidedly higher in a group of $21 \mathrm{X}$-ray-technicians and physicians than in the control group of as many university students.

4. The time-course of the effect was investigated after momentary exposure to $50 \mathrm{mr}$, and two phases, acute and chronic, were distinguished. The acute effect lasted for a few days, declining rapidly. A residual effect of several per cent of the maximum remained for over 10 days (chronic phase).

5. There was an approximately linear relationship between the maximum acute effect and the logarithm of the applied dose within a range from $1 \mathrm{mr}$ to $50 \mathrm{mr}$.

\section{References}

1) Loutit, J. F., Brit. J. Radiol., 1955, 28, 647.

2) Motokawa, K., Umetsu, J. \& Kobayashi, M., Tohoku J. Exp. Med., 1956, 64, 151.

3) Umetsu, J., ibid., 1956, 64, 325.

4) Kohata, T., Komatsu, M. \& Motokawa, K., Jap. J. Physiol., 1956, 6, 236.

5) Wakabayashi, M., Kawamura, F., Akatsu, S., Nakayama, Y., Yoshikawa, A., Matsui, M., Iizima, M., Tahara, T., Motonaga, K., \& Ueda, K., Tohoku J. Exp. Med., 1958, 67, in press.

6) Helde, M. \& Wahlberg, T., Act. Radiol., 1953, 40, 435. 